\title{
Anne M. Gilroy, Brian R. MacPherson, Lawrence M. Ross, Markus Voll, Karl Wesker: Atlas of anatomy
}

\section{Thieme Verlag, Stuttgart, New York, 2008, 656 pp, numer. figs, $€$ (D) 69.95 CHF 116,00 (Softcover), ISBN 978-1-60406-062-1 (Softcover), ISBN 978-1-60406-151-2 (Hardcover)}

\author{
Pierre Kehr
}

Received: 16 August 2009/Accepted: 18 August 2009/Published online: 30 August 2009

(C) Springer-Verlag 2009

This atlas of anatomy covers the entire human anatomy in a single volume. The beautifully coloured drawings stand out with highly detailed accuracy. Just like any other atlas, the text amounts to the legends of the figures, although numerous $\mathrm{x}$-rays and endoscopic views complement the drawings. Synoptic charts show an outline of muscle insertions, nerve and muscle functions as well as arterial territories. This book also offers a comprehensive index allowing for rapid search of the content.

It should be on the bookshelves of every teacher or student dealing with human anatomy.

No funds were received in support of this study.

Pierre Kehr Strasbourg

P. Kehr $(\bowtie)$ 